\title{
The Church of Saint Clement, the Pope: Sources and the Symbolism of the Image in Russian Folklore
}

\author{
Lyudmila Fadeyeva \\ Department of Folklore and Folk Art \\ State Institute for Art Studies \\ Moscow, Russia \\ volfs@list.ru
}

\begin{abstract}
This article is based on some variants of the Russian spiritual verse Golubinaya Kniga [Pigeon book] and on a few Russian charms from the handwritten collections (from the 17th and 19th centuries). In all these texts an image of the Church of Saint Clement, the Pope, is mentioned as a sacred place. In charms it becomes a place where the personages who help the protagonist usually stay. The legendary plot about the church of Saint Clement, which appeared on the place of his death at the bottom of the Black Sea and then used to come in sight from the sea every year in memory of his martyr's death, is well known from the old Christian literature. The author considers the hagiography and iconography sources of this image and pays special attention to the icons of $\mathrm{St}$. Clement with a cycle of his life on the margins that come from the Russian North. This stuff seems to influence the folklore tradition and as a result produces the specific image of the Christian shrine in spiritual verses and charms.
\end{abstract}

Keywords-Old Russian hagiography; Old Russian iconography; Russian spiritual verses; charms from the Russian North

\section{INTRODUCTION}

The name of St. Clement, the Pope1, is rarely mentioned in Russian folklore, but there are some magical charms and prayers from the Russian North where it is found. Quantitative data do not allow considering him among Christian saint patrons that are of a great importance in Russian charms [3] [4]. Nevertheless, this does not mean the destiny of St. Clement as a personage of charms is of no interest.

It is remarkable that St. Clement, the Pope, is named among saints authoritative both for the Russian religious tradition in general and for its local north version. We have such an example in the cattle-breeding magical prayer,

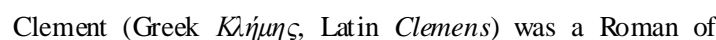
Greek origin. He lived in the $1^{\text {st }}-$ the early $2^{\text {nd }}$ century. According to the church lore, he was the disciple of apostles Peter and Paul, and in 88-97 (or 92-99) he was the Pope. Legends about his martyr death in the Crimea became popular in the 6th century. It's considered that it's the geographical proximity of these Greek lands to Kievan Rus' that promoted distribution of worship of the hieromartyr at residents of the Old Russian state, newly converted in Christianity. The Russian Church celebrate the memory of the saint on the $25^{\text {th }}$ of November Julian (the $8^{\text {th }}$ of December Gregorian) [1] [2]. obviously reflected relig ious preferences of inhabitants of the Russian North. It includes a long list of names of saint patrons, which is given in a not quite strict hierarchical sequence. Moreover, St. Clement takes an intermediate place in it as if he connects Greek, Roman and Russian church traditions [5].

In Russian charms the name of St. Clement is usually connected with the theme of the sea and also with an image of a church, standing in / at the sea. The aim of my research is to explore the sources of this image and to trace semantic transformations which it undergoes in Christian literary texts, iconography and folklore.

\section{THE HISTORY OF CULT IN RUSSIA}

At first we ought to touch briefly upon the history of the cult of St. Clement, the Pope, in Russia. It was almost apostolic in the beginning - from the end of the 10th to the middle of the 13th century [6]. Within this period, it was developing at first in Kiev and then was expanding into farther areas. However, later on this cult became gradually weaker and then nearly died away. However, in the $16^{\text {th }}$ and the first half of the $17^{\text {th }}$ century the North Russian icon painters were showing a real interest in the history of St. Clement. They were decorating the churches, constructed in his honor, with the icons, including some episodes from the history of his life.

It is well known that a religious worship of St. Clement goes back to the traditions of Saints Cyril (or Constantine) and Methodius. According to Constantine the Philosopher's hagiography, on arrival to Chersonese in 861 he began to search for the place, where relics of the martyred pre late lay, and he opened that "saint Clement still lies in the sea"2. He took the relics from the sea, and then the part of it accompanied "the Slav teachers" during their travel in borderlands of the Greek-Roman world. Their mission encouraged a wide spreading of St. Clement's cult at the Slavic lands.

${ }^{2} \mathrm{~V}$. Toporov wrote that it was "too courageous an image" in the hagiography's text. Actually it meant a low island opposite Chersonese which was gradually going under, and it had almost been flooded by the time St. Constantine tried to find it [7]. 
But in Kiev Rus' the beginning of this cult was connected most of all with the activity of Saint Prince Vladimir. According to the legend fixed in his hagiography and in early Russian chronicles, he transferred to Kiev the other part of St. Clement's relics obtained through the Korsun war campaign. He put them in a special altar of the first Russian stone church of Blessed Virgin Mary, well known as the Desiatinnaia church, in Kiev. From this time St. Clement was perceived as the first holy patron of Russia, its apostle, and his memory was highly significant for a Christian life of Kiev. Annually on the 30th of January, on the very day when the holy relics were found by Constantine the Philosopher, a solemn service was held in the Desiatinnaia church (it is testified by calendar of the Ostromir Gospel of 1056-1057). This day was also celebrated in other Old Russian menologions of $11^{\text {th }}-14^{\text {th }}$ centuries [8]. St. Clement's relics remained in the Desiatinnaia church as one of the main sacred objects of Kiev up to the moment of its destruction in 1240 by the troops of Batu khan. There aren't any reliable facts of their further destiny [9].

Today we can judge a special reverence for St. Clement, the Pope, by the works of art of early period of Russian Christian history. They are, first, early Russian literary texts, translated and original, which have reached our time; they are mosaics and murals of churches, which were created by ancient Greek masters ordered by Russian customers. Now it is possible only to assume that the most ancient image of St. Clement in Kiev was in murals of the altar devoted to him in the Desiatinnaia church where the head of the saint was stored as a sacred relic [10]. According to art critics, "the iconography of his personal appearance and also the plots of his hagiography extended across all Russian lands exactly from here. And it is highly probable that a considerable part of these samples of more ancient origin, produced still in Chersonese, could be brought to Kiev from Korsun in the form of manuscripts or icons as a part of Prince Vladimir spoils of victory" [11]. Although now it is possible to see a mosaic image of St. Clement in a rank of holy hierarchs in an altar of St. Sophia's Cathedral in Kiev (the 1040 ${ }^{\text {th }}$ ).

\section{THE IMAGE OF ST. CLEMENT IN OLD RUSSIAN ART AND LITERATURE}

The expansion of St. Clement's cult to the Russian North was marked with the construction of the stone city cathedral in his honor in Old Ladoga (1153) and with an inclusion of his image in murals of an apse of St. Georgy's Church located in the same town ("A Service of St. Fathers", the last quarter of the 12th century). St. Clement was depicted at an upper tier of holy hierarch's rank of the Savior's Church on Nereditsa, near Novgorod, where he was represented next to St. Nicholas the Wonderworker (1199). There is a cycle of murals devoted to St. Clement in the Transfiguration of Christ Cathedral of the Mirozhsky Monastery in Pskov (between 1136 and 1156). It reflected the hagiography of the saint in the most remarkable way. Here scenes of St. Clement's acts and miracles are given in the same part with acts of apostles (two upper tiers in arches represent scenes of apostles' sermon and Peter's and Paul's histories, and in the lower tier the episodes of St. Clement's life are located). Unfortunately, some frag ments of these murals were lost and they aren't read any more [12] [13].

The interest in St. Clement's hagiography was also supported by a large number of icons. On the majority of the early icons (the 13th -17 th centuries) he was represented standing before Enthroned Jesus Christ or Virgin Mary and praying, frequently among the other saints most venerated in Russian tradition. There is St. Nicholas, the Wonderworker; the Hieromartyr Blaise (in Russian "Vlasij"), Bishop of Sebaste; the Greatmartyr Parasceva, nicknamed Piatnitsa ("Friday"), and so on [14]3. St. Clement's icons, created in the Russian North at the end of 16th - the early 17th century, include detailed cycles of his hagiography in their margins. So they show what episodes of his life and what legends about his miracles were most attractive to the Russian people at this time.

Legendary motives of St. Clement's life were fixed by Greek texts which were translated further by Slavic and Old Russian scribes. A big block of these compositions was included later in the Great menologion by metropolitan Makarij (the $16^{\text {th }}$ century). Different versions of hagiography of the saint tell about his parents' and brothers' lives full of melodramatic episodes, his discipleship of the apostle Peter, service in Rome and the exile to remote Chersonese, where he overthrew idols, baptized people and also found a spring of water. One of the most expressive points of this narration was the story about St. Clement's martyr death, that is to say, how he was thrown by his persecutors into the sea with an anchor on his neck, and a mysterious church appeared after that on this very place, and the sea waters moved away from this place to show the church with the relics of the martyr. These events are described in "The Martyrdom of Saint Clement", the well-known Greek source, existing in numerous Slavic and Russian versions of translations [16].

The first Russian original work about St. Clement where there is a miracle with the church, coming out of the sea, is "The Lay on a Renovation of the Desiatinnaia church". It is considered to have been written in the $11^{\text {th }}$ century. Another interesting literary monument of the same time - the Russian version of "The Miracle about an Adolescent", known from manuscripts of the $14^{\text {th }}-17^{\text {th }}$ centuries, - is closely connected with it [17]. This is a very free retelling of a Greek "Legend on Saint Clement's Miracle over the Adolescent" which is attributed to Yefrem, the bishop of Chersonese, living in the 4th century. According to researchers, the Russian version substantially differs from the Greek original [18].

In "The Miracle" the Russian author shows in detail the execution of St. Clement who refused to make a sacrifice to idols. He tells that pagans wanted to deprive Clement's disciples of the opportunity to bury their teacher and to give him the necessary honors, but suddenly the church appeared in the sea. The author pays the main attention to a seven-day pilgrimage to this church of inhabitants of nearby places: their staying at relics and praying to St. Clement, and a grief

\footnotetext{
${ }^{3}$ About Novgorod icons of the $13^{\text {th }}$ century see [15]
} 
that occurred with one of the families that forgot their son near the reliquary. Only having returned to the city, the father and mother understood that their son hadn't come back with the other pilgrims. In despair they rushed to the coast, but it was too late: the sea had returned to its usual place. The parents mourned themselves and their boy, reproaching the cruel saint: here was his answer to their prayers! The next year, on the day when the sea parted again, they came back to the place of death of the child. They hoped at least to find his body and to bury him as it befits Christians. But a miracle awaited them: their son met them in the sea church of St. Clement, staying at the very place where they had left him. The evidence of the miracle was in the words of the boy who answered the questions of his parents: "Who guarded you? Who fed you?" The author "draws" an illustration of this episode, showing with his words how the adolescent, "holding with one hand at the reliquary and pointing with a finger of the other hand towards the saint, lying in it, answered his asking parents: "Here he is - my guard with the God. He fed me, he protected me against the attacks of sea beasts, he kept me all the time"" [19].

This plot was very popular. Icons of "Holy bishop Clement, the Pope, with scenes from his life" exactly reproduce the episode with the rescued adolescent. Icon painters use the same gesture of the boy in the scene of his conversation with his parents, and they imprint the image of the church, which appeared in the sea at the place of the martyr's death, where the event took place. As an example I can refer to two well-known North Russian icons: one, being dated the mid-16th century, from St. Nicholas church of the village of Nyonoksa, Arkhangelsk region (the icon is in the collection of Arkhangelsk Museum of Fine Arts), and another, from the end of 16th - the beginning of the 17th century, from Solvychegodsk, probably, also from Saint Clement's church (now it is in the State Hermitage). On the first icon we see episodes "The overthrow of Clement in the sea", "Clement's relics rest in the chapel at the bottom of the sea" "Fig. 1", "Clement's miracle about an adolescent" "Fig. $2 "$ in a cycle of 13 remained border scenes (the lower tier is lost). On the second, in a cycle of 20 border scenes, there are episodes "Clement's execution by drowning" and two scenes of "Cle ment's miracle about the adolescent" [20] [21] [22].

Many researchers consider that the "Legend on Saint Clement's Miracle over the Adolescent" promoted the birth of one more Old Russian legend about a rescue of a child from drowning - "The Miracle about a child of St. Nicholas, Archbishop of Myra in Lycia" [23]. And it's true, that the sea miracles of St. Nicholas, The Wonderworker, - for example, "about three men" and "about one man Dimitrij", being rescued from drowning, - were similar to a sea miracle of Clement of Rome. Therefore, the birth of the Old Russian legend on the crossing of the two cults of holy hierarchs seems quite natural. And this is one of the probable reasons of the two archbishops' shared depicting on the icons (for example, a Novgorod icon of the second half of the 13th century "The Mother of God on the throne, with Nicholas and Clement standing before Her" from the State Russian Museum collection and an icon of the 14th century on the same plot of northern Rostov tradition - from Vologda State
Historical and Architectural Art Museum Reserve). They are both "Sea Wonderworkers".

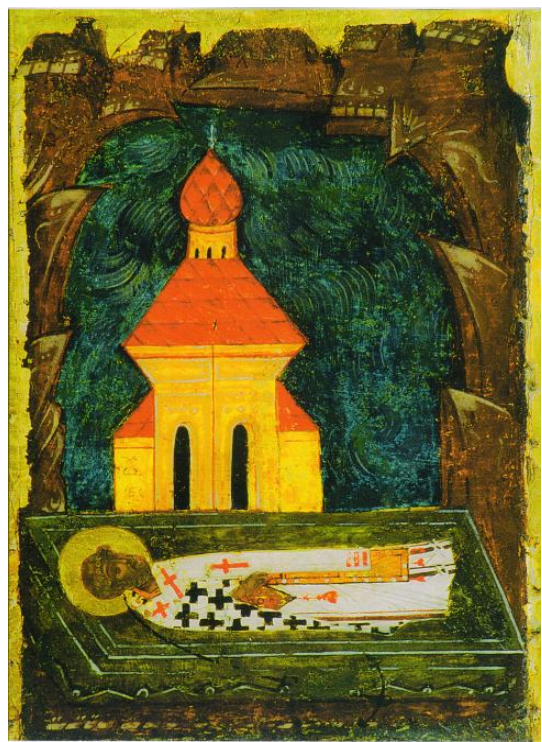

Fig. 1. St. Clement's relics rest in the chapel at the bottom of the sea. The fragment of the icon "Holy bishop Clement, thePope, with scenes from his life". The mid- $16^{\text {th }}$ cent ury. Arkhangelsk Museum of Fine Arts.

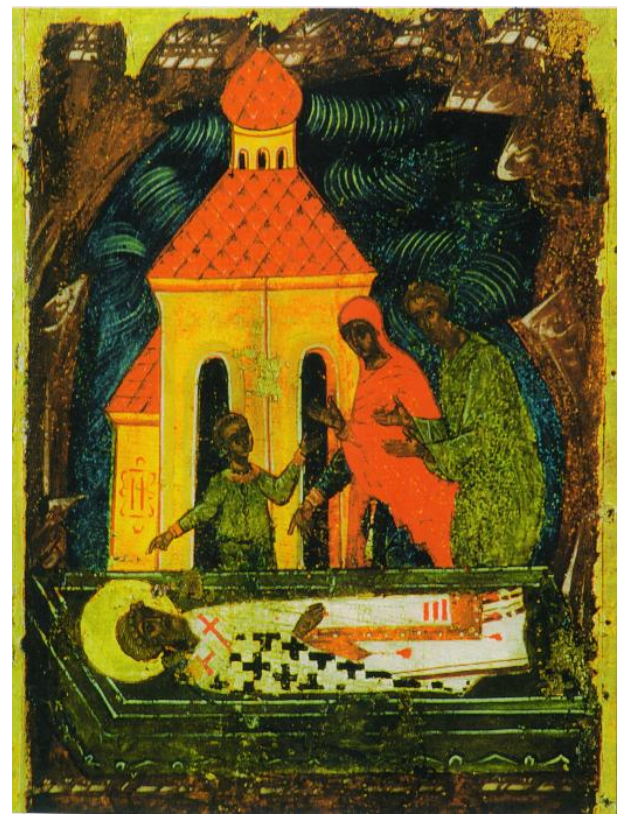

Fig. 2. St. Clement's miracle about an adolescent. The fragment of the icon "Holy bishop Clement, the Pope, with scenes from his life". The mid16 th century. Arkhangelsk Museum of Fine Arts.

\section{THE IMAGE OF ST. CLEMENT IN RUSSIAN FOLKLORE}

It is important that the charm from the most famous in Russian magic folklore Olonets' collection of the 17th century calls Clement exactly "the Sea Wonderworker" [24]4.

\footnotetext{
${ }^{4}$ Reprinted in [25].
} 
Such "title" of the saint in this case wasn't connected with the aim of the text, directed on curing of bleeding wounds from spears, arrows, swords, axes and knives. Therefore, the compiler of the text hailed St. Clement by using his constant characteristic which had settled in tradition. Certainly, it was finally fixed owing to "The Miracle about an Adolescent" and the further development of beliefs in the saint as the rescuer from drowning. And as for the connection of St. Clement's and St. Nicholas' images, that might be the real reason for a strange plural number in the charm from the Olonets' collection where Clement is the only saint-assistant. Perhaps, the name of Nicholas the Wonderworker was omitted by the copyist of the text.

A folklore assimilation of motifs and images, connected with the book and iconographic sources of Saint Clement's hagiography, is a specific problem. As an example, it is worth looking through the texts, using the image of the mysterious church, appearing / standing in the sea. In folklore this image receives a generalized sense as a spatial symbol - one of holy places, connected with God's presence. A spiritual verse "Golubinaya Kniga" [Pigeon Book] and a prose novel "The tale about Volot Volotovich", related to it, name all the main shrines and miracles of the Christian world, and they mention Saint Clement's church among them [26]. Here is how "The tale about Volot Volotovich" tells about it: "...А море Окиянъ всем морям мати: велико и пространно. И на Окияне море стоит церковъ Божия, а в ней опочивают мощи Климента, папы римъскаго; потому и мати всем морямъ Окиянъ" [...And the Ocean Sea is the mother of all the seas: it is great and vast. And on the Ocean Sea there is a God's church, and over there the relics of Clement, the Pope, rest, therefore the Ocean is the mother of all the seas] [27]5. And here is how this image develops in a spiritual verse "Golubinaya Kniga" [Pigeon Book]:

...Окиян море всем морям мати.

- Почему жь Окиян море всем морям мати?

110. Обкинуло то море вокруг землю всю,

Во нем Окияне во мори пуп морской;

С-по д восточной со сторонушки

Выставала из моря церковь соборная

Со двенадцатью со престоламы, 115. Святу Климанту, папы Римскому,

Святу Петру Александрийскому, -

Потому ж Окиян море всем морям мати...

[...The Ocean Sea is the mother of all the seas.

- Why is the Ocean Sea the mother of all the seas?

This sea embraces all the Earth around,

And there is a navel of the sea in the Ocean Sea;

${ }^{5}$ To compare see also a consolidated text, according to four manuscripts of "The Tale...", in [28].
The cathedral church

Of Saint Clement of Rome,

Of Saint Peter of Alexandria,

With twelve altars

Rose from the sea,

From under the East side -

Therefore the Ocean Sea is the mother of all the seas...]

or:

...Океан море всем морям мати.

- Почему Океан всем морям мати?

150. - Посреди моря Океанскаго

Выхо дила церковь соборная,

Соборная, богомольная,

Святого Климента, попа Рымскаго:

На церкви главы мраморныя,

155. На главах кресты золотые.

Из той из церкви из соборной,

Из соборной, из богомольной

Вы хо дила Царица Небесная;

Из Океана моря она омывалася,

160. На собор-церковь она Богу молилася:

От того Океан всем морям мати...

[...The Ocean Sea is the mother of all the seas.

- Why is the Ocean the mother of all the seas?

- The cathedral church, the prayerful church

Of Saint Clement, the priest of Rome,

Came out in the middle of the Ocean Sea;

There are marble domes on the church,

There are golden crosses on the domes.

From this cathedral church, from this prayerful church

Our Lady of Heaven came out;

She had a wash in the Ocean Sea,

She read a prayer to God at a cathedral church:

Therefore the Ocean is the mother of all the seas...]

[30].

In spiritual verses the literary image undergoes a specific working up. It directs towards an aesthetic representation of the shrine ("На церкви главы мраморныя, / На главах кресты золотые" [There are marble domes on the church, / There are golden crosses on the domes]) and an emphas is of 
its scale ("Со двенадцатью со престоламы" [With Twelve Altars]). But the image undergoes some semantic transformations as well. A church, rising from the sea, becomes a symbol of the universal Church - a part of the Kingdom of Heaven, which is all-embracing, thus it has a place everywhere, and on the bottom of sea too. It is significant that Virgin Mary stays here. But at the same time the relics of the martyr aren't mentioned in these fragments at all. The church has his name, but it is impossible to understand from the text why. However we can see more features of literary legend in some variants of "Golubinaya Kniga" [Pigeon Book]. In the consolidated text, published by P. Bessonov, we meet the following details: "выходит раз в год церковь соборная / божественная" [a cathedral / divine church comes out once a year], "что во той во церкви во соборныя / стоит гробница на воздухах бела каменна, / в той гробнице белокаменной / почивают мощи па́па Римскаго... па́па Римскаго, слава́-Клементьева" [in that in cathedral church / there is a white stone tomb in the air, / in that white stone tomb / there are the relics of the Pope... the Pope, Clement, the Glorious] [31].

As one of the important symbols of Christianity the church of St. Clement is used by Russian charms. In their "sacred geography" it becomes a symbol of a sacred centera place, where the protagonist goes: "...Пойду я, раб Божий, ко святу Окияну морю, есть свять остров там; на святе острову лежит белый камень Латер; на том камне стоит церковь Папы Римской [sic]; в ефтой церкве стоит злат пристол; на злате пристоле сидит сам Исус Христос, Матерь Божья, Цариця небесная, в злате ризе, держит золото перо и смахивает, и спихивает, и сдувает, сметает со свята Окияна желту пену..." [...I'll go, the servant of God, to the sacred Ocean Sea, there is a sacred island there; on the sacred island the white stone Latyr lies; on that stone there is a church of the Pope; in this church there is a golden altar; on this golden altar there is Jesus Christ, the Mother of God, Our Lady of Heaven, in golden clothes, she holds a gold feather and brushes off, and pushes away, and blows out, and sweeps away a yellow foam from the Ocean...] [32]. A personage-assistant, curing an illness, usually stays here: "Есть море Киян, на море Кияне стоит остров, на том острове воздвигнута церковь Климента Папы Римского, в той церкви святая девица, а имя ей Анастасия. Держит она у себя разные иглы и шелковою нитью зашивает она рану кровавую..." [There is the Kean Sea. There is an island on the Kean Sea. There is a church of Clement, the Pope, constructed on the island. There is a holy maiden in the church, her name is Anastasia. She holds different needles and sews up a bleeding wound with a silk thread...] [33].

An understanding of St. Clement's church as one of the symbols of the Kingdom of Heaven can involve an aesthetical working up of the image in charms (as it was in spiritual verses). And as a result it looks sometimes like a real "icon in words": "..Посмотрю аз, раб Божий ..., на все четыре стороны, а есть на восточной стороне Окиана моря, на углу стоит храм св. Климента, Папы Римскаго; на нем поставлен крест златой; на кресте написан Сам Господь Иисус Христос и четыре Евангелиста: Лука,
Марк, Иоанн, Матвей. Помолюся аз, раб Божий ..., самому Христу небесному, и Пречистой Его Матери, и четырем Евангелистам и стану отговариваться от колдунов, от колдуньи, от шептуна, от шептуньи, от старца и старицы, от всякаго злаго человека, от рабов и рабынь, от верных и неверных..." [...I, a servant of God..., will look at all four sides. And there is a church of Clement, the Pope, on the East side of the Ocean Sea, on the corner. There is a golden cross on it. The Lord Jesus Christ and four evangelists - Luke, Mark, John, Matthew - are depicted on it. I, a servant of God..., will pray to the heaven Christ himself, and to his Most-Pure Mother, and to four evangelists, and I'll begin to break the spell of sorcerers, of a sorceress, of a whisperer, of a whisperess, of an old man and an old women, of any evil man, of slaves, of faithful and unfaithful...] [34]. But not only the idea of the beauty of the church is conveyed in these words. The place is magnificent and its parts look like an icon because it has a great significance. The golden cross is not only the "cross on the dome" here. It is an equivalent of an altar, that is to say, an absolute top of sacred center - the very place where the saint-assistants stay in the charms.

Moreover in this magical prayer (from Cherepovets county of Novgorod region) the image of St. Clement's church is used very functionally. The aim of this prayer is to protect the wedding procession from evil and sorcery. For the ceremony, where it works, the idea of the way is of primary importance. Consequently, spatial images play a big role in its verbal ritual texts. In the magical prayer the move from the yard to church - "промежду вечернею зарею и утреннею ко святому морю Окиану" [between the evening and morning dawn to the sacred Ocean Sea] - is a road between two golden crosses, and the protagonist (quite possibly in this case it is the groom's best man) bows and prays to them at the beginning and at the end of his way. This is the same movement to the sacred center, and its highest point is St. Clement's church, standing on the East side of the Ocean Sea. However in a projection to reality it may be understood as the safe movement of a wedding procession, going into a bride's house and then into a church - "следы мои травой заростают и песком засыпают, водой заливают" [my traces are overgrown with grass, and filled up with sand and with water]. Therefore, we have a reas on to raise again a question of the universal character of the image of St. Clement's church, appeared from the sea, as an all-e mbracing Church, personifying all churches, existing in the Christian world. It means by itself that real, quite concrete church where the wedding procession has to bring the groom and the bride.

\section{CONCLUSIONS}

The folklore image of St. Clement's Church, appearing / standing in the sea, has its origins in the cycle of legends about St. Clement, the Pope, and of his miracles, fixed in hagiography of the hieromartyr. In the Russian cultural and religious tradition they date from the epoch of the baptism of Russia. During the centuries the image of St. Clement's Church was getting a constant place in people's religious mind, and the visual representation of the episodes of St. 
Clement's life on murals and hagiographic icons was very helpful in this process.

The appeal to St. Clement in magical prayers and charms (and references to his church as well) can be connected with the special veneration of the saint in some areas and places. In Russia, the magic texts, using his name, were spread mostly in the North, in the areas located close to the sea. There were many churches of St. Clement here because he was venerated as a "Sea Wonderworker".

The plot about the sea shrine has a detailed presentation in literary pieces and iconography, connected with them. In folklore - in spiritual verses and especially in magical prayers and charms - it is reflected only as a hint, a short mention of the miracle. But it obtains an important symbolic meaning of the universal sacred place.

\section{REFERENCES}

[1] V. L. Zadvornyj, Clement. Works. The worship in Russia, in Catholic encyclopedia, vol. 2. Moscow: Publishing House of Franciscans, 2005, col. 1074.

[2] Y. Vinogradov, A.A. Turilov, Clement. The worship in Rus, Orthodox encyclopedia, vol. 35. Moscow: Church scientific center Orthodox Encyclopedia, 2014, p. 456.

[3] V. Yudin, Onomastic dictionary of Russian charms: Proper names in the Russian magic folklore. Moscow: MONF, 1997, pp. 101-102.

[4] A. L. Toporkov, ed., The Russian charms from handwritten sources of $17^{\text {th }}$ - the first half of the $19^{\text {th }}$ century. Moscow: Indrik, 2010, p. 175.

[5] L. N. Maykov, Russian spells. St.Petersburg: Publishing house of the European house, 1994, p. 119.

[6] V. D. Sarabyanov, E.S. Smirnova, History of Old Russian painting. Moscow: St. Tikhon's Orthodox University, 2007, p. 22

[7] V. N. Toporov, Constantine the Philosopher in "Hagiography", in V.N. Toporov, Sanctity and saints in the Russian spiritual cult ure, vol. 1: The first century of Christianity in Russia. Moscow: Gnozis; School "Languages of the Russian Culture", 1995, pp. 113-118.

[8] A. Y. Karpov, The most ancient Russian pieces of writing about $\mathbf{S}$. Clement of Rome, in Essays on feudal Russia, vol. 11. Moscow, St. Petersburg: Alliance-Arkheo, 2007, p. 5

[9] V. D. Sarabyanov, Worshipped saints of pre-Mongolian Russia in murals of St. Sophia in Kiev. Part 1: On the formation of local tradition, in Art Studies, NN 3-4. Moscow: State Institute for Art Studies, 2014, p. 55.

[10] S. P. Zaigraykina, Clement. Iconography, Orthodox encyclopedia, vol. 35. Moscow: Church scientific center "Orthodox Encyclopedia", 2014, p. 460.

[11] V. D. Sarabyanov, Worshipped saints of pre-Mongolian Russia in murals of St. Sophia in Kiev. Part 1: On the formation of local tradition, pp. 56, 60 .

[12] V. D. Sarabyanov, E.S. Smirnova, History of Old Russian painting, p. 117.

[13] V. D. Sarabyanov, Worshipped saints of pre-Mongolian Russia in murals of St. Sophia in Kiev. Part 1: On the formation of local tradition, pp. 58-61.

[14] S. P. Zaigraykina, Clement. Iconography, Orthodox encyclopedia, vol. 35 , p. 460.

[15] T. Y. Tsarevskaya, The image of St. Clement of Rome in Novgorod art of the $13^{\text {th }}$ century, Old Russian art: Byzantium and Ancient Russia. To A. N. Grabar's $100^{\text {th }}$ anniversary (1896-1990). St. Petersburg: Dmitry Bulanin Press, 1999, pp. 260-273.

[16] A. Y. Karpov, The most ancient Russian pieces of writing about St. Clement of Rome, Essays on feudal Russia, vol. 11, pp. 3-110.
[17] Ibid., pp. 3, 56, 69-73.

[18] Ibid., p. 73

[19] Ibid., p. 99.

[20] O. N. Veshnyakova, T. M. Koltsova, eds., Northern Paintings. The collection of Arkhangelsk Museum of Fine Arts: Catalogue. Arkhangelsk: North-west Publishing House, 1999, p. 55.

[21] O. N. Veshnyakova, T. M. Koltsova, L. V. Nersesian, A. S. Preobrazhensky, Icons of Northern Russia: The masterpieces of ancient Russian painting in Arkhangelsk Museum of Fine Arts, vol. 1. Moscow: Northern Pilgrim Publishing House, 2007, pp. 226-235.

[22] S. P. Zaigraykina, Clement. Iconography, Orthodox encyclopedia, vol. 35 , p. 461.

[23] O. A. Ustinova, To literary history of the text of the Miracle about a child, in St. Nicholas, Archbishop of Myra in Lycia, in monuments of literature and iconography. Moscow: St. Tikhon's Orthodox University, 2006, p. 59 .

[24] V. I. Sreznevsky, The description of the manuscripts and books, collected in Olonets Region for Empire Academy of Sciences. St. Petersburg: typ. of Empire Academy of Sciences,1913, p. 485.

[25] A. L. Toporkov, ed., The Russian charms from hand-written sources of 17 th - the first half of the 19th century, pp. 97-98.

[26] V. Mochulsky, Historical and literary analysis of the verse about Golubinaya kniga [Pigeon Book]. Warsaw: M. Zemkevich typ., 1887, pp. 123-131.

[27] A. V. Markov, The Tale about Volot and its relation to The tale about the sacred city of Jerusalem and to a verse about Golubinaya kniga [Pigeon Book], in The News of the Department of Russian language and literature of Empire Academy of Sciences, vol. 18, book 1. St. Petersburg, 1913, p. 33.

[28] F. I. Buslayev, ed., Russian anthology: The monuments of Old Russian literature and folklore with historical, literary and grammatical explanations, with a dictionary and an index. Moscow: typ. Grachev и Сo., 1870, p. 330

[29] P. A. Bessonov, The vagrant cripples: Collection of verses and research, vol. 1, issue 2. Moscow: typ. A. Semena, 1861, pp. 288-289.

[30] Ibid., pp. 303-304.

[31] Ibid., p. 361

[32] N. N. Vinogradov, Charms, averters, saving prayers and so on: (According to ancient manuscripts and modern records), part 2, in Live antiquities: Journal of Department of Ethnography of Empire Russian Geographical Society, vol. 4, appendix. St. Petersburg: Typ. Ministry of Communication lines, 1908, pp. 86-87 (№ 96 and much closed to it № 98 from the same manuscript from Cologriv district of Kostroma region).

[33] Shchurov, Charming in Russia, Readings in Empire Society of Russian History and Antiquities at the Moscow University, vol. 4. Moscow, 1867, p. 166.

[34] L. N. Maykov, Russian spells, p. 27. 